\title{
GOOGLE CLASS ROOM: PANDUAN MENGELOLA KELAS DARING DI SMPN 27 PADANG
}

\author{
Yessy Prima Putri, Andrew Kurniawan Vadreas \\ STMIK Indonesia Padang \\ yessy@stmikindonesia.ac.id
}

\begin{abstract}
The purpose of the training activities is so that teachers at SMP 27 Padang can conduct online learning online at home without face-to-face with students. The method chosen is by providing training. The results of this community service activity are practical and simple guidelines in the form of guidelines for teachers at SMP 27 Padang to understand and understand using the Google Classroom application

Keywords: training, google classroom
\end{abstract}

\begin{abstract}
Abstrak
Tujuan dari kegaitan pelatihan agar guru di SMP 27 Padang bisa melakukan pembelajaran daring secara online melalui rumah tanpa tatap muka langsung dengan siswa. Metode yang dipilih dengan cara memberikan pelatihan. Hasil dari kegiatan pengabdian masyarakat ini adalah panduan praktis dan sederhana berupa pedoman bagi guru di SMP 27 Padang agar paham dan mengerti menggunakan aplikasi google classroom.
\end{abstract}

Kata Kunci: pelatihan, google classroom

\begin{tabular}{l|l|l} 
Submitted: $2021-06-16$ & Revised: 2021-07-26 & Accepted: 2021-07-31
\end{tabular}

\section{Pendahuluan}

Di tengah masa Pandemi Covid-19 ini kebijakan pemerintahan memberlakukan pembelajaran dari rumah yaitu pembelajaran secara daring (Suhery, 2020). Secara tiba-tiba pembelajaran di sekolah yang semula yang sifatnya tatap muka berubah menjadi pembelajaran secara daring. Hal ini membuat semua dari tenaga pendidik harus mengikuti kebijakan dari pemerintah untuk belajar mengajar secara daring. Meskipun beberapa daerah telah menyatakan diri memasuki new normal (masa kenormalan baru), tetapi pelaksanaan pendidikan selain zona hijau, tetap melakukan BDR (Belajar Dari Rumah).

Pandemi covid-19 ini memiliki dampak besar bagi lapisan masyarakat. Tak terkecuali pada sektor pendidikan. Semua lembaga pendidikan yaitu sekolah terjadi penutupan pembelajaran tatap muka antara siswa dan guru (Ai'zahra Qisthi, 2019). Termasuk Sekolah Menengah Pertama (SMP) 27 Padang yang berada di di Kecamatan Kuranji. Pembelajaran diganti dengan pembelajaran daring untuk menghindari penyebaran covid 19 ini. Pembelajaran daring ini dilakukan supaya para siswa tidak ketinggalan pelajaran yang ada. Karena memang dampak dari pandemi ini terus menerus terjadi berbulan bulan dan belum pasti kapan akan berakhir.

Ketercapaian hasil belajar memang sangat dipengaruhi oleh berbagai unsur-unsur. Unsur yang paling utama adalah unsur guru, siswa, kurikulum, dan unsur sarana-prasarana pendukung pembelajaran. Guru-guru, khususnya di SMPN 27 Padang memakai model pembelajaran dengan hanya menumpukan guru sebagai pemberi ilmu (information delivery) dan metode latihan yang digunakan masih dirasakan kurang bermakna bagi hasil belajar mahasiswa. Salah satu aplikasi pembelajaran yang cocok digunakan untuk saat ini adalah Google Class Room. Belajar saat ini menjadi lebih mudah, karena didukung oleh berbagai teknologi yang semakin maju.

Untuk itu, maka tim PKM Sekolah Tinggi Manajemen Informasi dan Komputer (STMIK) Indonesia Padang, merasa bertanggungjawab untuk bersama-sama sosialisasi penggunaan aplikasi Google Classroom terhadap tenaga pendidik di SMP 27 Padang. 
Rumusan masalah yang akan dibahas adalah (1) Kurangnya pemahaman dan pengetahuan tenaga pendidik di SMP 27 Mata Padang tentang pemakaian Google Classroom; dan (2) Terkendala kondisi sebagian guru di SMP 27 Padang yang gagap teknologi atau gaptek dalam penguasaan teknologi informasi (TI).

Tujuan yang ingin dicapai dari kegiatan pengabdian pada masyarakat ini adalah (1) Membekali tenaga pendidik SMP 27 Padang agar memiliki pemahaman dan pengetahuan tentang Google Classroom; (2) Membantu memberikan pengetahuan dan pemahaman tentang pemakaian Google Classroom; (3) Memberikan contoh cara pemakaian Google Classroom.

Manfaat yang diharapkan dari kegiatan pegabdian masyarakat ini adalah (1) Peserta memahami pengetahuan pemakaian Google Classroom untuk diterapkan pada saat mengajar siswa/siswi; (2) Peserta menyadari akan pentingnya pengetahuan pemakaian Google Classroom agar mudah cara pembelajaran secara daring; (3) Peserta mengetahui dan memahami cara pemakaian aplikasi Google Classroom.

\section{Metode}

1. Permasalahan

Kegiatan belajar-mengajar jarak jauh masih terkendala kondisi sebagian guru yang gagap teknologi atau gaptek dalam menggunakan perangkat komunikasi. Dinas Pendidikan (Disdik) Kota Padang mengakui masih adanya masalah tersebut. Permasalahan dalam pembelajaran daring adalah kemampuan guru dalam penguasaan teknologi informasi (TI). Padahal, ini sangat diperlukan mengingat pandemi Covid-19 belum jelas kapan akan berakhir.Untuk mengatasi persoalan tersebut, tim PKM Sekolah Tinggi Manajemen Informasi dan Komputer (STMIK) Indonesia Padang mencoba membantu mitra dengan memberikan pengetahuan dan pemahaman aplikasi google classroom.

\section{Pemecahan Masalah}

Adapun Metode yang dilakukan dalam pelatihan pembelajaran daring ini adalah dengan cara pelatihan secara langsung. Tujuannya agar guru dapat memahami materi pelatihan dengan baik dan bisa mempraktikkannya secara langsung.

Langkah-langkah yang dilakukan pada kegiatan pelatihan ini adalah:

1. Menerapkan protokol Kesehatan sebelum, ketika dan sesudah melakukan pelatihan.

2. Memperkenalkan tentang pembelajaran daring.

3. Menjelaskan tentang google classroom beserta cara penggunaannya.

3. Khalayak Sasaran

Khalayak sasaran sosialisasi penggunaan aplikasi zoom meeting dan google classroom pada guru di SMP 27 Padang, dengan jumlah guru yang diikutsertakan dalam pelatihan ini sebanyak 33 orang.

1. Perencanaan Materi

Sebagai pendahuluan dalam kegiatan ini, maka dilakukan konfirmasi terkait dengan media yang dimiliki guru untuk dijadikan media dalam proses pembelajaran daring apakah berupa HP atau laptop. Karena rata-rata guru menggunakan HP, maka sebelum menjelaskan bagaimana cara menggunakangoogle classroom dalam proses pembelajaran, guru diminta untuk mendownload aplikasi pembelajaran google classroom melalui play store. Setelah semua selesai menginstall aplikasi google classroom, selanjutnya dijelaskan Langkah-langkah penggunaan google classroom.

2. Waktu dan Tempat Pelaksanaan

Pelaksanaan kegiatan pengabdian masyarakat ini dilaksanakan pada pada tanggal 9 Juni 2021, bertempat di SMP 27 Padang. 


\section{Hasil dan Pembahasan}

Adapun Metode yang dilakukan dalam pelatihan pembelajaran daring ini adalah dengan cara pelatihan secara langsung. Tujuannya agar guru dapat memahami materi pelatihan dengan baik dan bisa mempraktikkannya secara langsung.

Langkah-langkah yang dilakukan pada kegiatan pelatihan ini adalah:

1. Menerapkan protokol Kesehatan sebelum, Ketika dan sesudah melakukan pelatihan. Dalam proses pelaksanaan pelatihan para guru dengan teratur mengikuti protokol Kesehatan yang sudah dibuat oleh panitia pelaksana. Dari mulai pengecekan suhu tubuh, menjaga jarak, memakai masker selama pelaksanaan pelatihan dan tidak berkumpul di satu tempat sebelum. ketika dan sesudah pelatihan.

2. Memperkenalkan tentang pembelajaran daring. Pada bagian ini pemateri menyampaikan tentang berbagai media yang dipergunakan dalam pembelajaran daring termasuk google classroom. Dari penjelasan yang disampaikan para peserta telah memahami kekurangan dan kelebihan dari masing-masing aplikasi pembelajaran yang dijelaskan.

3. Menjelaskan tentang google classroom beserta cara penggunaannya, seperti (1) Membuka aplikasi google classroom; (2) Membuat kelas; dan (3) Meng-copy kode kelas

4. Praktik pengunaan google classroom

\section{Kesimpulan}

Dari kegiatan pengabdian yang telah dilakukan, maka diperoleh hasil bahwa peserta sangat berminat dengan pelatihan ini. Penambahan pengetahuan bagi peserta tentang penggunaan aplikasi google classroom yang baik dan benar, serta secara cepat dengan menerapkan secara langsung.

\section{Daftar Pustaka}

Ai'zahra Qisthi, A. S. (2019). Bimbingan Belajar Secara Daring Guna Membantu Siswa Dalam Kegiatan Belajar Mengajar Dimasa Pandemi Di Kecamatan Simo. Universitas Negeri Semarang.

Suhery. (2020). Sosialisasi Penggunaan Aplikasi Zoom Meeting Dan Google Classroom Pada Guru Di Sdn 17 Mata Air Padang Selatan. Jurnal Inovasi Penelitian, 1(3 Agustus), 129-132. 